\title{
References:
}

1. Doronina, T. O. (2012). Theory and practice of gender education and upbringing of students in educational institutions of Ukraine (II half of XX - early XXI century): author. dis... dr. ped. sciences: 13.00.01 - general pedagogics and history of pedagogics. National Academy of Pedagogical Sciences of Ukraine; Institute of Higher Education. Zaporozhye, 36 p.

2. Legislation of Ukraine. Available at: http://zakon.rada.gov.ua/cgi-bin/laws/ main.cgi?nreg=2866-15

3. History of the term «gender». Available at: http://lektsii.com/1-108143.html

\section{PSYCHOLOGICAL AND PEDAGOGICAL ASPECTS OF EDUCATION OF VALUABLE ATTITUDE OF HIGH SCHOOL STUDENTS TO PARENTS}

\section{Yuliia Pinihina $^{1}$}

\section{DOI: https://doi.org/10.30525/978-9934-26-002-5-10}

New trends in the development of society, the peculiarities of building family relations in modern sociocultural conditions actualize the problem of forming attitudes towards parents as a value of high school students.

The works of psychologists A. Zdravomyslov, V. Karakovsky, V. Tugarinov, I. Bekh, I. Beletskaya, N. Dyatlenko, I. Lapchenko, S. Tishchenko, Y. Prykhodko, S. Kulachkivska, V. Kutyshenko, S. Lupynovych and teachers A. Ulanovsky, D. Shchelkunov, T. Kuidina, T. Galenko, I. Sharonova, O. Zhebrovsky, D. Kuzminska, O Polovina, S. Kovalenko, N. Lebedeva, N. Kubay, H. Barna, A. Pogorelova are devoted to the problem of bringing up of children's valuable attitude.

Values are objects or phenomena that are important to the subject. Among the generally accepted values in society, everyone chooses the most important for himself and relies on them. I. Bekh, believes that «values are those which are reflected by the subject of the sphere of his existence, through which he distinguishes himself.., it is a formation where "personal» and «external», «about objective» are gathered» [1, p. 210]. All elements of the value system are interconnected, intersected and have a hierarchy that is not stable and can be changed under the influence of certain factors and circumstances. Advantages of some values over others are shown in interactions, relations a person with all surrounding.

\footnotetext{
${ }^{1}$ Bogdan Khmelnitsky Melitopol State Pedagogical University, Ukraine
} 
Valuable attitude is a system of human relations with the world, considered by us as an integral personal quality, which can be defined as a direction of personality emotions, due to a set of needs that determine the characteristics of activities and behavior.

V. Gorbatykh believes that the valuable attitude has a complicated psychological meaning and includes emotional, cognitive and behavioral components [3]. We believe that the emotional component in the structure of the valuable attitude is leading, because the attitude of the individual arises in the process of a kind of imposition of his emotions on the subject, which is realized to a certain extent, known by him.

The realization of the valuable attitude can be carried out basing on the current needs and interests of the individual, for which it is necessary to choose such pedagogical technologies that involve the use of methods and techniques that stimulate the emotional perception of values. Emotions are invariably associated with values, which are the core of emotions, as emotions are often directed at a particular object.

One of the important conditions for the assimilation of significant values by senior students is the awakening of emotional experiences in them, because, as many researchers note, there is no relationship without emotions, there is only indifference. In some cases, emotions, such as fear, are not aroused to assimilate values, but as an independent process. A person for his normal development must experience the full range of emotions, including negative ones.

In our opinion, the key indicators of values towards oneself and others are feelings, which include: respect for the native land, deep knowledge of one's origins, native language, culture, history of the people, humanity, care for the young, empathy for those in grief, justice, tolerance, responsibility, fidelity to customs and love for parents and relatives. Doctor of Pedagogical Sciences, Lyudmila Moskalyova notes that «love for the individual should not be the opposite, but, on the contrary, acquire a harmonious combination, where the dominant is the love for the individual..., therefore, the desire for his benefit» [2, p. 226].

Valuable attitude to parents are an important component of personality education, where the main content is the need for emotional experience of high school students in the process of learning family values, as well as the relevant motives and interests. Values are emotionally experienced; their presence causes positive emotions of joy, admiration, pleasure. Conversely, the absence, loss of values causes negative emotions - resentment, anger, irritation. Therefore, values are learned on the basis of transformation of the received information as a result of its preliminary estimation. 
Thus, the education of valuable attitude towards parents is possible in the conditions of organized pedagogical work, which takes into account the main psychological channels of relationship formation and stages of assimilation of values.

The purpose of pedagogical efforts is a comprehensive impact on the personality of the senior student, which occupies the cognitive and emotional sphere and determines his practical activities, which ultimately increases the level of development of values. Therefore, the study on the education of valuable attitude of high school students to parents is based on a system of gradual transformation of socially significant value into personally significant, which ensures the sequence of assimilation of values and their application in practice. This sequence has the following construction: emotional perception of information - obtaining and understanding new information - the practical application of the acquired material.

Familiarization with the content is carried out at the stage of emotional perception of information, which serves, influencing emotions and feelings, to adjust students to active perception not only of direct feelings, but also with emotions. Therefore, it is important to involve information that evokes emotional stimulation.

At this stage, students' activities are organized in such a way that it brings new emotions, new information about the family. We consider it appropriate to hold problem discussions that promote cognitive needs (students' awareness of the value of the family for themselves): components of family well-being, the influence of family traditions on the attitude to parents as values, the formula of a happy marriage, types of family upbringing, etc. Issues related to maintaining a positive attitude towards parents reveal the value of the family, which promotes interest in the family and forms a cognitive need that determines the further formation of the attitude towards parents as a value.

The stage of emotional perception of information logically leads to the stage of obtaining new information aimed at familiarization and understanding of the content of the studied material, when connections are established between new and previously learned material, students get acquainted with concepts that have value (principles, ideals, actions). At the same time, the student gives his own assessment of the material, which gives it actual importance and contributes to personal reassessment of values. The selection of material takes into account the age of students, their cognitive interest, the activities of students focused on awareness of the personal significance of the studied material, encouraging students to emotional assessment. Performing tasks, students analyze the obtained information and the process of its assimilation for compliance or inconsistency with their own views and family 
values, which contributes to the development of skills and abilities of selfrealization. At this stage, dialogic forms of students' communication, techniques are used: a story with elements of heuristic conversation, etc. In general, at this stage, the activities of students are focused on the knowledge acquisition about families on the basis of personal assessment of the studied knowledge, which reveals the value of the family.

At the next stage - the stage of practical application of the learned material students realize the need to act on the basis of learned values, which contributes to the formation of conscious actions in specific activities and behavior, appropriate use of pedagogical situations, workshops, presentations and making projects. An important area is the extracurricular form of work, which allows you to purposefully introduce students to the family values. The effectiveness of this type of work increases when it is conducted in the form of business games in school.

Thus, in modern society, the valuable attitude of high school students to their parents is the basis of education, self-realization of students.

\section{References:}

1. Bekh, I. (2003). Vykhovannja osobystosti [Education of personality]. Kyiv: Lybid, 280 p. (in Ukrainian)

2. Moskalyova, L. (2011). Kharakterystyka suchasnykh pidkhodiv u vykhovanni majbutnikh vchyteliv [Characteristics of modern approaches in the education of future teachers]. Collection of scientific works of Uman State Pedagogical University, vol. 2, part 2, pp. 224-232. (in Ukrainian)

3. Gorbatykh, V. (2013). Samostavlennja osobystosti jak emocijnyj komponent samosvidomosti [Self-identity as an emotional component of self-awareness]. Bulletin of Zaporizhia National University, vol. 2, no. 13, pp. 48-52. (in Ukrainian) 